\title{
COMMON SIGNS AND DIFFERENCES BETWEEN THE DISCOURSE OF TEACHERS IN THE CZECH AND SLOVAK REPUBLICS ON THEIR PROFESSIONAL DEVELOPMENT AND \\ CAREER GROWTH
}

\author{
[SPOLOCNE ZNAKY MEDZI DISKURZOM UCITELOV \\ O PROFESIJNOM ROZVOJI A KARIERNOM RASTE \\ V CECHACH A NA SLOVENSKU]
}

\author{
Jaroslav Penicka
}

doi: 10.18355/PG.2019.8.2.6

\begin{abstract}
The aim of improving the educational process and the results associated with it is declared as a priority objective in the Czech and Slovak environments. The path of professionalization of teachers may be conceptual for improving the quality of education. The professional development of a teacher becomes a central category. The paper aims to present the results of research dedicated to the discourse of teachers about professional development and career growth in the Czech and Slovak Republics. For the discourse analysis, as the central design, research uses a qualitative approach in research. Using modelling in the focus group, discourse characterization categories are created through grounded theory and open coding. Despite the absence of career growth in the Czech Republic, the central category for participants in both countries is their internal motivation for further education - being a better teacher for their pupils. There is a negative attitude of teachers towards the ability of the state to assess who is a "good" teacher through career stages in Slovakia in relation to the career system; then the Czech Republic is accentuated by what criteria the state will do. Based on the participant's arguments, the author assumes that the system of in-service training should provide teachers with opportunities for further education. The primary function should be to ensure the quality and diversity of in-service training programs, as well as to provide teachers with opportunities and freedoms to participate.
\end{abstract}

\section{Key words}

teacher, professional development, career growth, motivation, discourse, qualitative methodology

\section{Anotácia}

Ciel' skvalitnit' edukačný proces a s ním spojené výsledky, je v Českom a v Slovenskom prostredí deklarovaný ako prioritný ciel'. Koncepčným východiskom skvalitňovania školstva môže byt' cesta profesionalizácie pedagógov. Ústrednou kategóriou sa stáva profesijný rozvoj učitel'a. Ciel'om príspevku je predstavit' výsledky výskumného zámeru zameraného na diskurz učitel'ov o profesijnom rozvoji a kariérnom raste v Čechách a na Slovensku. Pre analýzu diskurzu bol ako ústredný dizajn zvolený kvalitatívny prístup vo 
výskumne. Pomocou modelovania vo fokusovej skupine sú prostredníctvom zakotvenej teórie a otvoreného kódovania vytvorené kategórie charakterizujúce diskurz. Aj napriek absencii kariérneho rastu v Českej republike, ústrednou kategóriou pre participantov je $\mathrm{v}$ oboch krajinách ich vnútorná motivácia $\mathrm{k}$ d’alšiemu vzdelávaniu, byt' lepším učitel’om pre svojich žiakov. Pokial' na Slovensku v súvislosti s kariérnym systémom prevláda negatívny postoj $\mathrm{k}$ schopnosti štátu prostredníctvom kariérnych stupňoch posúdit', kto je kvalitný učitel', tak v Česku je akcentovaná obava, na základe akých kritérií to bude štát robit'- strach z neznámeho. Na základe tvrdení participantov autor zastáva názor, že systém d’alšieho vzdelávania by mal učitel'om poskytovat' možnosti, ako sa d'alej vzdelávat', jeho funkciou by malo byt' zabezpečit' kvalitu a rozmanitost' programov d'alšieho vzdelávania rovnako, ako poskytovat' učitel'om možnosti a slobody, ako sa do neho zapojit'.

\section{Kl'účové slová}

učitel', profesijný rozvoj, kariérny rast, motivácia, diskurz, kvalitatívny prístup vo výskume

\section{Úvod}

Ciel' skvalitnit' edukačný proces a s ním spojené výsledky, je v Českom a Slovenskom prostredí deklarovaný ako prioritný ciel' (programové vyhlásenie vlád v nadväznosti na dokumenty $\mathrm{OECD}$, UNESCO, Európskej komisie). Vychádzajú z celosvetovej snahy upevnenia a zvýšenia postavenia učitel’a (Charta učitel'a, Bolonská deklarácia), snahy o zmenu paradigmy nazerania na učitel'a, zvýšenie jeho kvalifikácie prostredníctvom celoživotného vzdelania. Koncepčným východiskom skvalitňovania sa školstva v Českom a Slovenskom prostredí, súhlasiac s názorom autorov Kosovej, Pavlova, Porubskeho, Tureka, Spilovovej, Vasutovej, Walterovej, Kohnovej, sa javí často akcentovaná cesta profesionalizácie pedagógov - prostredníctvom štandardizácie činností učitel'a a na nich nadviazaných d’alších dokumentov, ktoré predpokladajú učitel'ovu profesionalitu, ako ústredný činitel' reforiem $\mathrm{v}$ školskom prostredí. Ústrednou kategóriou sa stáva profesijný rozvoj učitel'a, ktorý je definovaný (Stary, 2012, s.12) ako „.. súbor aktivít vedúcich $\mathrm{k}$ zdokonal'ovaniu výkonu profesie a skvalitňovanie výsledkov učenia žiakov“. Kariérny rast (progresívny postup v kariérnom systéme) je na Slovensku ukotvený Zákonom 317/2019 Z.z., v Českej republike je aj napriek viacerým iniciatívam vychádzajúcich zo štandardizácie („Učitel“ (1996), Walterova a Vasutova (2001), „Kariérní řád“ (2017)) stále nefunkčný, aj ked’ legislatívne prostredníctvom Zákona č. 563/2004 Sb. ukotvený. Súčasnú situáciu vzdelávacej politiky je možné sledovat' prostredníctvom medzinárodných výskumných šetrení napríklad OECD TALIS, kedy môžeme konštatovat' rozdielnosti vo vnímaní súčasného stavu d'alšieho vzdelávania učitel'ov, ktoré sú spôsobené rozdielnym legislatívnym ukotvením d’alšieho vzdelávania učitel'ov v jednotlivých krajinách (Penicka, 2018). Potrebné je zdôraznit', že vnímanie a následný diskurz súčasného stavu môže byt' z pohl'adu učitel'ov iný než platná legislatívna. Dôvodom je, že diskurz, ako ustálený výsledok subjektívnej a intersubjektívnej zdiel'anej 
transformácie reality, je konštruovaný určitou predstavou o realite (reprezentácii), ktorá ako komplexná symbolická forma zastupuje realitu. Napríklad, povinnost' absolvovat' adaptívne vzdelávanie na Slovensku neznamená, že ho učitelia vnímajú, že subjektívne zažívajú takúto formu vzdelávania (výsledky TALIS 2013). Práve preto je v súvislosti so zist'ovaním súčasného stavu nutné opierat' sa nielen post quem racionalizovat' kvantitatívne výskumné šetrenia, ale aj interpretovat' diskurz prostredníctvom názorov učitel'ov.

\section{Charakteristika výskumného šetrenia (ciele, metódy, výskumná vzorka, spôsob spracovania dát, limity)}

Ciel'om výskumného šetrenia je zodpovedat' otázky: 1) Aká je motivácia učitel'ov ku profesijnému rozvoju a kariérnemu rastu? 2) Aké motivačné faktory sú z pohladu učitel'ov najdôležitejšie pre ich profesijný rozvoj a kariérny rast, a ako ich interpretujú samotní učitelia?

Výskumná metóda (modelovanie $\mathrm{v}$ ohniskovej skupine) bola konštruovaná $\mathrm{s}$ ciel'om poskytnút' informácie o diskurze a minimalizovat' ovplyvnenie participantov výskumníkom. Ako ukazuje Figure č.1, využíva kvalitatívny prístup vo výskume. Zakotvenú teóriu považuje metóda za dizajn kvalitatívneho prístupu vo výskume. Dôvodom výberu je, že je induktívne odvodená zo skúmania javu, ktorý reprezentuje. Je vytvorená a operatívne overovaná systematickým zhromažd’ovaním údajov o skúmanom jave a ich analýzou. Zdrojmi dát sú analýza prameňov a rozhovorov, a zúčastnené pozorovanie, ktoré metóda využíva.

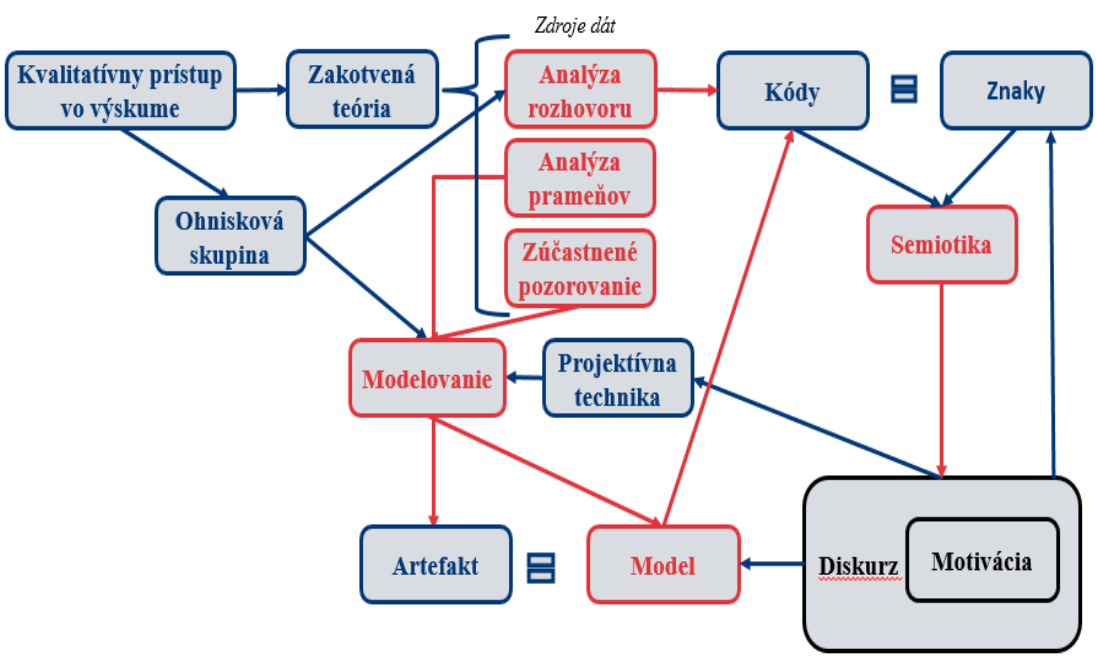

Figure 1:Modelovanie v ohniskovej skupine

Zvolené modelovanie - tvorivá l'udská činnost', ktorá sa vyznačuje idealizáciou a zjednodušením reálneho sveta a predstavuje určitú formu zobrazenia reality. Model chápe ako zjednodušenú formu zobrazenia podstatných znakov skúmaného úseku reality. $\mathrm{Na}$ vytváranie modelu nahliadame ako na projektívnu techniku z neanalytického poňatia (Svoboda, 
2010, s. 149) ako na proces, v ktorom jedinec premieta obsahy svojich duševných procesov navonok, pripisuje ich iným alebo ich nachádza $\mathrm{v}$ iných lud'och, zvieratách, rastlinách, dejoch a predmetoch $-\mathrm{v}$ výskume sa premieta do modelu, ktorý predstavuje katalyzátor, pretože predpokladá externalizáciu správania.

Výskumné šetrenie bolo realizované v rokoch 2016/7 Slovenská republika, 2017/8 Česká republika. Výskumnú vzorku tvorilo 48 učitel’ov v 8 ohniskových skupinách na Slovensku (Bratislava, Nitra, Banská Bystrica) a 24 učitel'ov v 6 ohniskových skupinách v Českej republike (Praha, Plzeň, Karlove Vary). Možno konštatovat', že neimplementovaním systému „Kariérní řád“ v Českej republike bola $\mathrm{v}$ negatívnej miere ovplyvnená tendencia participantov zúčastnit' sa výskumu z dôvodu neaktuálnosti problematiky. Učitelia boli vybratí na základe participácie na kurze vzdelávacieho programu $\mathrm{v}$ Metodicko-pedagogickom centre a v Národní institutu pro další vzdělávání, až na dva prípady, nepôsobili na rovnakej škole, ako iný účastník skupiny. Participanti pochádzali z rôznych typov škôl: prvý a druhý stupeň ZŠ, gymnázium, SŠ, SOŠ, SOU, konzervatórium, dížka ich pedagogickej praxe bola 2-34 rokov.

Participantom boli pre minimalizovanie priamych otázok položené dve: „Čo si predstavujete pod pojmom profesijný rozvoj a kariérny rast?““ (analyzuje pojmový aparát participantov, ich osobné definovanie pojmov, slúžiace na d’alšie analyzovanie výrokov a identifikáciu znakov) a „Navrhnite pre vás optimálny model d’alšieho vzdelávania pre učitel’ov.“ (Otvára diskusiu, diskurz účastníkov o téme.)

Z ohniskových skupín boli spracované prepisy diskusií. Prikláňajúc sa k Glaserovmu poňatiu zakotvenej teórie, bolo primárne použité otvorené kódovanie výrokov na základe klúčových slov a tém použitých v rámci výrokov.

Limitom výskumného šetrenia je výber participantov do ohniskových skupín. Tým, že boli (podl'a cielov výskumného zámeru) vybraní iba účastníci, ktorí majú skúsenosti $\mathrm{s}$ d’alším vzdelávaním a účast' bola dobrovol'ná, výskumné dáta sú aplikovatel'né iba pre učitel'ov, ktorí sa chcú d’alej vzdelávat'. Tento limit je však na druhú stranu prínosný pretože opisuje diskurz práve tých učitel'ov, ktorí sa chcú d'alej vzdelávat' a tak je možné určit' kategórie, čo konkrétne ich viedlo k ich d’alšiemu vzdelávaniu.

\section{Výsledky výskumného šetrenia}

Nasledujúce kategórie, ktoré sú saturované pre všetky ohniskové skupiny. Centrálne kategórie vyvodené z otvoreného kódovania (Figure č. 2) sú spoločné pre diskurz $\mathrm{v}$ oboch krajinách - Česká republika a Slovenská republika, pre obsah príspevku sú predstavené v kontextovo viazanom texte. 


\begin{tabular}{|l|l|l|}
\hline $\begin{array}{l}\text { Slovenská } \\
\text { republika }\end{array}$ & Spoločná kategória & Česká republika \\
\hline Kredity & Profesijný rozvoj & prestiž učitel'skej profesie \\
\hline Tabulka & Kariérny rast & Integrácia \\
\hline Iný odbor & Dobrý učitel & Psychohygiena (učebné volno) \\
\hline Odborná literatúra & Lektor & Financovanie \\
\hline & Teoretické/praktické kurzy & Čas \\
\hline & Diskusie s inými učitel'mi & \\
\hline & Riaditel školy & \\
\hline & Podpora & \\
\hline & Možnost vol'by & \\
\hline
\end{tabular}

Figure 2: Saturované kategórie otvoreného kódovania

Profesijný rozvoj - definovaný účastníkmi, ako vnútorná motivácia predstavuje, najpresnejšie popísanú kategóriu, ktorá pre selektívne kódovanie plní funkciu centrálnej kategórie. Odpovede respondentov poukazujú na to, že učitelia, ktorí participujú na d’alšom vzdelávaní (sa profesijne rozvíjajú) tak robia preto, aby sa stali lepšími učitel'mi pre svojich žiakov. Učitelia, ktorí participujú na d’alšom vzdelávaní očakávajú, že toto ich vzdelávanie zefektívni prácu s triedou, že budú môct' efektívnejšie predávat' vedomosti učit'.

Kariérny rast - v slovenskej strane častokrát definovaný, ako Vonkajšia motivácia, nepredstavuje pre učitel'ov v oboch krajinách výrazný motivačný činitel'. Kariérny rast - niečo, podl'a čoho budú hodnotení - niečo, čo rozlišuje medzi kariérnymi stupňami - nepredstavuje pre učitel'ov výrazný motivačný činitel' hlavne $\mathrm{z}$ dôvodu, že $\mathrm{v}$ skutočnosti priamo nesúvisí $\mathrm{s}$ výukou, ide iba o indikátor, ktorý môže, ale nemusí, byt' funkčný. Je to niečo, s čím sa nestotožňujú. V Českej republike učitelia častokrát definujú profesijný rozvoj ako kariérnu cestu stat' sa zástupcom riaditel'a, resp. riaditel'om školy.

Dobrý učitel' - dobrý učitel' je medzi ohniskovými skupinami kategória, ktorú učitelia často v súvislosti s profesijným rozvojom a kariérnym rastom používajú. Na jednej strane ju využívajú, ked' učitelia veria $v$ to, že existuje Entita dobrého učitel'a - učitel'a, ktorý je inšpiratívny, popud vhodného nasledovania. Učitelia majú záujem stretnút' sa s takým učitel'om - vidiet', ako taký učitel' vyučuje. Na druhej strane sú presvedčení, že štát nedokáže určit', kto je kvalitným učitel'om. Práve preto učitelia na Slovensku neveria systému kariérneho rastu, systému, ktorý škatul'kuje/zarad'uje/člení/rozdel'uje pretože tento systém označuje učitel'ov do rôznych kategórií. Pričom indikátory, ktoré využiva - atestácie, počet kreditov - nie sú pre učitel'ov dôveryhodnými. Učitelia $\mathrm{v}$ Českej republike prezentujú obavy nad zavádzaním takýchto kritérií a kladú si rovnaké otázky ako tie. ktoré učitelia na Slovensku považujú za diskutabilné. 
Teoretické/praktické kurzy - učitelia preferujú praktické kurzy d’alšieho vzdelávania, dôvodom je hlavne ich očakávanie od profesijného rozvoja pomôct' s zefektívnit' edukačný proces. Teda, pokial' je kurz, ktorý učitel' navštevuje praktický. Ak je učitel' presvedčený o tom, že mu kurz priamo pomôže $\mathrm{v}$ rámci jeho výuky, je kurz ako taký pre učitel'a omnoho motivujúcejší, ako kurz teoretický, v ktorom nenachádza žiadny prínos. i V ideálnom prípade prostredníctvom kurzu uvidí dobrého učitel'a, ktorý ho inšpiruje, bude výuku reflektovat' a prostredníctvom nadobudnutých informácií zmení svoju výuku. Teoreticky zamerané kurzy, ktoré obsahujú l'ahko dohl'adatel'né informácie, sú z toho pohl'adu irelevantné. Ako hovoria participanti zo Slovenska, môžu sa k ním dostat' kedykol'vek prostredníctvom odbornej literatúry, metodík a internetu, od d’alšieho vzdelávania očakávajú viac, prakticky efektívnejšiu formu.

Lektor (vyučujúci v d’alšom vzdelávaní) - Predstavuje významný motivačný činitel' pre učitel'ov. Súvisí už so všetkými spomínanými kategóriami. Na jednej strane očakávajú od lektora, že im pomôže v profesijnom rozvoji, na druhej strane majú od neho aj očakávania ako od dobrého učitel’a - odborník na d'alšie vzdelávanie učitel'ov. Učitel' sa počas kurzu d’alšieho vzdelávania dostáva do pozície „žiaka“, od lektora očakáva, že mu prakticky ukáže, čo by mohol robit’ so žiakmi. V tom bode sa projektuje do osoby lektora - „dobrého učitel'a“ a očakáva, že sa prostredníctvom nej niečo naučí. Logiku participantov - to čo funguje na mňa, bude fungovat' aj na mojich žiakov - je možné nájst' vo viacerých príkladoch, napríklad učitel' cudzieho jazyka, ktorý má skúsenosti so stážami bude označovat' túto formu vzdelávania ako vhodnú aj pre svojich žiakov.

Diskusie s inými učitel'mi - dôležitým spoločným bodom pre oba diskurzy je význam profesijného vzdelávania, ako možnost' diskusie s inými učitel'mi. Jedným z najväčších prínosov kurzov d’alšieho vzdelávania je, že sa na ňom môžu učitelia stretnút' $\mathrm{s}$ učitel'mi $\mathrm{z}$ iných škôl. $\mathrm{V}$ ideálnom prípade je učitel'om počas kurzov ponúknutá možnost' vyjadrovat' svoje skúsenosti, hodnotit' možnost' implementácie prezentovaných riešení a ich limity. V najhoršom prípade už stretnutie s učitel'mi z iných škôl otvára pre účastníkov témy, ktoré súvisia s edukačným procesom na inej škole, aj ked' táto forma nepatrí medzi najefektívnejšie, pôsobí okrem vzdelávacieho aspektu aj terapeuticky.

Možnost' vol'by - v súvislosti s profesijným rozvojom je kruciálna zložka práve vol'ba učitel'a zvolit' si d’alšie vzdelávanie o ktoré má záujem. Učitelia ako vel'ká heterogénna skupina majú rôzne preferencie. Práve preto nie je možné určit plošné riešenie - jeden definovaný systém d’alšieho vzdelávania. Učitel' ako autonómny profesionál má preferencie a kritéria pre svoje d’alšie vzdelávanie. Preto je pre neho dôležité zvolit' si to, čo považuje za vhodné. Nutné je zdôraznit', že do tejto vol'by by mu nik nemal zasahovat', ani mu ju určovat'. Pretože práve to ovplyvní jeho d’alšiu motiváciu.

Riaditel' školy - vo všetkých ohniskových skupinách často vyskytujúca sa postava, ovplyvňujúca je profesijný rozvoj učitel’ov, je vnímaná ambivalentne. Príklady o tom, ako riaditel' podporuje d'alšie vzdelávania učitel'ov, ako vytvára podmienky pre ich profesijný rast, sú častokrát oponované s príkladmi, ked' riaditel' školy neumožňuje učitel'ovi d’alší 
profesijný rozvoj - neumožňuje mu navštevovat' kurzy d'alšieho vzdelávania, respektíve odmieta opodstatnenost' učitel'ových požiadaviek.

Podpora - priznaná a zároveň nepriznaná kategória. Ako už prvá kategória opisovala, ciel'om profesijného rozvoja z pohl'adu učitel'ov je zvýšenia efektívnosti vyučovacieho procesu - byt' lepším učitel'om pre svojich žiakov. $\mathrm{Na}$ zefektívnenie tejto cesty je dôležitá podpora zo strany štátu - vytváranie takých podmienok aby minimalizoval prekážky $\mathrm{v}$ ceste d’alšiemu vzdelávaniu.

Medzi špecifické kategórie charakterizujúce diskurz na Slovensku patria kredity. Kredity pre respondentov predstavujú vonkajšiu motiváciu, ktorá je spojená s d'alším vzdelávaním - niečo, čo dostanú za to, že niekto absolvoval d'alšie vzdelávanie. Za najväčšie negatívum môžeme považovat' možnost' spojenia - vel'a kreditov rovná sa dobrý učitel'.. Učitelia otvorene priznávajú,, že ich motiváciou $\mathrm{v}$ súvislosti s kreditmi je priznanie zvýšenia platu. Je to súčast'ou pravidiel. Ďalšou, v médiách často akcentovanom témou, je platnost' kreditov. Zníženie platu z dôvodu nedostatku kreditov však nie je hlavným problémom $\mathrm{v}$ súvislosti $\mathrm{s}$ ich platnost'ou - kredity sa dajú získat' znova... Problém, o ktorom participanti hovoria, znie: „Pokial’ som získala nejaké kompetencie - dostala som kredity, tak po 7 rokov akoby som to všetko zabudla a môžem zahodit' certifikát.“.

$\mathrm{V}$ Českej republike je medzi respondentmi často akcentovaná téma financovania d'alšieho vzdelávania. Napriek informáciám zo šetrenia TALIS (2013) Českí učitelia ako prekážku vidia finančnú náročnost’ štúdia - okrem ceny kurzov aj logistiku. Participanti v Českej republike sú viac ochotní zaplatit' si za svoje d'alšie vzdelávanie, pokial' očakávajú, že im bude prínosné, ale zároveň poukazujú na to, že niektoré vzdelávania sú pre nich cenovo nedostupné.

\section{Záver}

Aj napriek absencii kariérneho rastu je ústrednou kategóriou pre participantov $\mathrm{v}$ oboch krajinách ich vnútorná motivácia $\mathrm{k}$ d’alšiemu vzdelávaniu, byt' lepším učitel'om pre svojich žiakov. Táto motivácia sa javí vel'mi úzko spätá s osobnost'ou učitel'a a preto je stabilná pre obe krajiny, rovnako ako prítomná v d'alších vyspelých krajinách (Louws, 2016). Pokial' na Slovensku v súvislosti s kariérnym systémom prevláda negatívny postoj $\mathrm{k}$ schopnosti štátu prostredníctvom kariérnych stupňoch posúdit', kto je kvalitný učitel', tak v Česku je akcentovaná obava, na základe akých kritérií to bude štát robit'.

Najsilnejšia motivácia učitel'ov $\mathrm{k}$ d’alšiemu vzdelávaniu je tá, že sa prostredníctvom neho stávajú lepšími učitel'mi. Najvhodnejšia forma d'alšieho vzdelávania je, o ktorej sú presvedčení, že bude mat' pozitívny vplyv na ich vyučovanie. Pokial' je forma funkčná, učitel' ju odporučí d’alšiemu učitel'ovi, čím zvýši jeho motiváciu ubezpečením o prínose. Tento pohl'ad však vyžaduje, aby učitelia mali podmienky pre d'alšie vzdelávanie, aby poskytované formy d’alšieho vzdelávania boli funkčné a aby sa mohli stretávat' $\mathrm{s}$ inými učitel'mi. Samotná participácia $\mathrm{v}$ systéme profesijného rozvoja a kariérneho rastu nie je $\mathrm{v}$ súlade $\mathrm{s}$ ideou „zvýšenie kvality edukačného procesu prostredníctvom systému profesijného rozvoja 
a kariérneho rastu“. Dôvodom je, že samotná participácia učitel'ov nemusí zaručovat' profesijný rozvoj a určite nie efektívny. Fakt, že systém prostredníctvom benefitov, ktoré nesúvisia s d’alším vzdelávaním sa učitel’a, umožňuje možnost' účasti iba pre získanie určitej výhody. Táto možnost' vo vel'kej miere deformuje samotný systém, pretože jednotliví aktéri (štát, riaditel' školy, učitelia navzájom) sa vzájomne podozrievajú z toho, že ich motivácia k participácii je zištná.

Preto v súvislosti s deklarovanými ciel'mi „skvalitnit' edukačný proces a $\mathrm{s}$ ním spojené výsledky, je pre štát dôležité akcentovat' nazeranie na problematiku "Ako sa učitel môže prostredníctvom systému PR KR profesijne rozvíjat". Dôležitost' tohto nazerania je v súvislosti s motiváciou učitel'ov kl'účová, pretože do hlavnej pozície stavia samotného učitel'a. "Ako podporit' učitel'a?", pričom slovo podpora je klúčové. Úlohou štátu je vytvárat' také podmienky pre učitel'ov, aby učitelia, ktorí sa chcú d’alej vzdelávat', sa vzdelávat' mohli, prihliadat' na názor učitel'ov a garantovat' kvalitu foriem d’alšieho vzdelávania - respektíve kontinuálneho vzdelávania.

Výskum byl podpořen Grantovou agenturou Univerzity Karlovy (projekt č.1110716).

\section{Bibliographic references}

KOHNOVA, J. 2004. Dalsi vzdelavani ucitelu a jejich profesni rozvoj. Praha: Univerzita Karlova v Praze - Pedagogicka fakulta. ISBN 80-729-0148-6.

KOHNOVA, J. 2012. Profesni rozvoj ucitelu a cile skolniho vzdelavani. Praha: Univerzita Karlova v Praze. IBSN 978-80-7290-625-3.

KOSOVA, B. 2007. Andragogicky pohlad na vzdelavanie a ucenia sa ucitelov. In Orbis scholae, vol 13, pp. 5-12. ISSN 1802-4637.

LAZAROVA, B. 2006. Cesty dalsiho vzdelavani ucitelu. Brno: Paido. ISBN 80-7315-114-6.

LOUWS, L. M. 2016. Professional learning: what teachers want to learn. 1. Leiden: Mostert \& van Onderen. ISBN 978-94-90383-16-9.

OECD 2013, Teaching and Learning International Survey: Conceptual Framework. Paris: OECD. Available online: https://www.oecd.org/education/school/TALIS\%20Conceptual\%20Framewor k_FINAL.pdf

OECD 2013, TALIS 2013 Results: An International Perspective on Teaching and Learning Paris: OECD. Available online: http://www.oecd.org/education/school/talis-2013-results.htm

PAVLOV, I. 2013. Standardizacia profesijnych kompetencii ucitelov vychodiska a perspektivy. Presov: Skola plus s.r.o. ISBN 978-80-970275-5-1. PENICKA, J. 2018 Komparacia Ceskej a Slovenskej republiky v vyskumnom setreni TALIS 2013 zamerana na profesny rozvoj ucitelov. In Aktualne teoreticke a vyskumne otazky pedagogiky $\mathrm{v}$ konceptoch dizertacnych prac doktorandov. Olomovc. /v tlači/

SPILKOVA, V. - TOMKOVA, A. 2010. Kvalita ucitele a profesni standard. Praha: Univerzita Karlova, Pedagogicka fakulta. ISBN 978-80-7290-496-9. 
STARY, K. - DVORAK, D. - GREGER, D. - DUSCHINSKA, K. 2012. Profesni rozvoj ucitelu: podpora ucitelu pro zlepsovani vysledku zaku. Praha: Karolinum. ISBN 978-80-246-2087-9.

SVOBODA, M. 2010. Psychologicka diagnostika dospelych. Praha: Portal. TUREK, I. - ZEMAN, M. - JAKUBCOVA, E. 1999. Navrh systemu vzdelavania pedagogickych pracovnikov $\mathrm{v}$ SR. Bratislava: Metodicke centrum. ISBN 80-8052-053-4.

VASUTOVA, J. 2007. Byt ucitelem: co by mel ucitel vedet o sve profesi. Praha: Univerzita Karlova v Praze, Pedagogicka fakulta. ISBN 97-880-72903.

Zakon c. 317/2009 Z.z.. O pedagogickych zamestnancoch a odbornych zamestnancoch a o zmene a doplneni niektorych zakonov. Slovenska republika, Available online: https://www.minedu.sk/data/att/2918.pdf

Zakon c. 563/2004 Sb. O pedagogickych pracovnicich a o zmene nekterych zakonu. Ceska republika Available online: http://www.msmt.cz/dokumenty/aktualni-zneni-zakona-o-pedagogickychpracovnicich-k-1-zari

Mgr. Jaroslav Pěnička

Katedra priprimární a primání pedagogiky, Pedagoggická fakulta Univerzita Karlova

Magdalény Rettigové 47/4, 11639 Praha 1- Nové Město-Nové Město

Česká republika

Jaroslav.penicka@pedf.cuni.cz 